\title{
Adelmo Genro Filho e o jornalismo
}

Daniel Koslowski HeRz

Foi jornalista formado pela Unisinos e mestre em Comunicação pela UnB. Foi professor do departamento de Comunicação Social/ Jornalismo da UFSC de 1980 a 1984. Fundador do Fórum Nacional pela Democratização da Comunicação e representante da Fenaj no Conselho Nacional de Comunicação do Congresso Nacional. Também foi um dos mentores da chamada Lei do Cabo, em específico dos parágrafos que asseguram a obrigatoriedade de TVs públicas e universitárias nos planos de TV por assinatura. Lançou em 1986 o livro "A História Secreta da Rede Globo", com grandes e sucessivas tiragens. Era primo de Adelmo Genro Filho. Morreu em 30 de Maio de 2006.

\section{Resumo}

Palestra proferida em 18 de agosto de 1988, no auditório do Centro de Convivência da UFSC, e que integra o seminário "Revolucionar o Marxismo", realizado em homenagem a Adelmo Genro Filho. Além dessa palestra, o evento teve outras duas mesas temáticas que aconteceram nos dias 17 e 19 de agosto respectivamente: "Adelmo Genro Filho e a Política", com palestras de Sergio Weigert e Vitor Schmidt; e "Adelmo Genro Filho e a Filosofia”, com palestras de José Miguel Quedi Martins e Sergio Weigert.

\section{Palavras-chave}

Teoria do jornalismo, Adelmo Genro Filho, Jornalismo brasileiro

\section{Artigo recebido em 24/05/2013}

Aprovado em 30/08/2013

\footnotetext{
1 Transcrição da conferência e notas de Felipe Simão Pontes, jornalista formado pela UEPG e mestre em Jornalismo pela UFSC. Atualmente, Felipe Pontes realiza seu doutoramento em Sociologia Política na UFSC e tem como objeto de estudo a teoria do jornalismo proposta por Adelmo Genro Filho. Integra o Núcleo de Estudos sobre Transformações no Mundo do Trabalho e o Grupo de Estudos e Pesquisa em Ontologia Crítica da UFSC e recebe bolsa auxílio da Capes.
} 


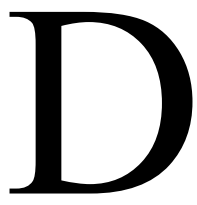
ividirei a exposição sobre Adelmo Genro Filho e sua produção sobre o jornalismo em três partes. Na primeira, apresentarei um histórico de como se desenvolveu a produção de Adelmo sobre o jornalismo². Em um segundo momento, exporei as principais concepções sobre o jornalismo incluídas no livro "O Segredo da Pirâmide". Em terceiro, destacarei alguns aspectos relevantes desse trabalho que se sobressaem pela originalidade e radicalidade e ultrapassam as questões específicas da área de jornalismo.

\section{I}

Fazendo um histórico de como se desenvolveu a produção de Adelmo sobre o jornalismo, podemos partir de uma constatação: de que quando ele cursou comunicação - assim como a maioria dos que hoje são professores aqui - não havia, tanto do ponto de vista político quanto do ponto de vista teórico, nenhuma possibilidade dessa discussão fluir através dos cursos de Comunicação. Por ser um espaço fechado, avesso a qualquer discussão minimamente crítica. Embora a luta fizesse com que os cursos refletissem a necessidade desse conhecimento crítico, as possibilidades eram mínimas.

Por isso, eu acho que uma das principais fontes de questionamento para Adelmo sobre o jornalismo foi uma experiência que nós tivemos - eu tive a oportunidade de participar com ele - que foi a criação, em 1975, do Semanário Informação ${ }^{3}$. Era um

2 Não é possível entender na íntegra as primeiras duas frases da palestra. Optou-se então, para dar coerência ao intento de publicar esse texto, reconstruir o trecho com base nas informações que estão dispostas na sequência da exposição. A partir desse trecho, a intervenção no texto ocorrerá apenas para dar mais fluidez à exposição em linguagem escrita.

3 Trata-se da experiência de dois jornais alternativos: o primeiro "Semanário de Informação Política" teve sede em Ijuí (RS) e foi veiculado de outubro de 1975 a abril de 1976; o segundo, "Jornal Informação" tinha sede em Porto Alegre e circulou de julho de 1976 a janeiro de 1977. Experiências citadas por Bernardo Kucinski em "Jornalistas e Revolucionários: nos tempos da imprensa alternativa" e que receberam estudo específico por Eloísa Klein na dissertação "Nas veias do jornalismo, a política: resistência à ditadura no Informação" (apresentada em 2008 no Programa de Pós-Graduação em Ciências da Comunicação da Universidade do Vale do Rio dos Sinos, sob orientação de Christa Berger). De acordo com Klein (2008, p. 78), Adelmo Genro Filho passa a aparecer como repórter do jornal de Ijuí apenas na edição de 6 de fevereiro de 1976. De acordo com relatos colhidos por Reis (2001, p. 124), a partir da entrada de Adelmo Genro Filho na redação e da composição de colaboradores de Santa Maria, o setor jovem do MDB passa a influenciar a guinada política do semanário de Ijuí. Daniel Herz, por sua vez, dirige o Jornal Informação de Porto Alegre, no qual Adelmo Genro Filho foi repórter e 
semanário que expressava as posições de uma articulação muito ampla que se situava, à época, em torno do MDB Jovem do Rio Grande do $\mathrm{Sul}^{4}$ e que reunia posições das mais variadas tendências. Examinando o expediente do Semanário, vamos verificar que há pessoas no $\mathrm{PCB}$, no $\mathrm{PC}$ do $\mathrm{B}$, no $\mathrm{PSDB}$, no PSB. Enfim, todas as principais correntes partidárias hoje estruturadas estavam agregadas ali naquele projeto. Esse leque muito abrangente representava quase uma síntese das oposições no Rio Grande do Sul nessa época.

Esse jornal acabou sendo também veículo de um debate que sustentava algumas candidaturas, inclusive a do próprio Adelmo em Santa Maria ${ }^{5}$. E foi bem sucedido nesse sentido, tanto é que nessas eleições ${ }^{6}$ - por essa articulação - foram eleitos dois vereadores em Santa Maria, Adelmo e Maria Rita ${ }^{7}$, e também em Porto Alegre, Marcos Klasmann ${ }^{8}$. Enfim, o jornal pretendia ser um veículo amplo, plural, das oposições.

Mas, a constatação a que nós chegamos era muito simples: ninguém sabia fazer jornal. O que se tinha de conhecimento técnico - que era muito primário em relação ao que existe hoje - era insuficiente para traduzir uma experiência militante e que também editor. Ambos os trabalhos não confirmam que Genro Filho e Herz participaram da fundação do jornal de Ijuí, mas apenas da fundação do de Porto Alegre.

4 Um estudo detalhado da composição do setor jovem do MDB gaúcho (e do grupo de Santa Maria) foi desenvolvido na dissertação de mestrado em Ciência Política da UFRGS "Juventude, Intelectualidade e Política: espaços de atuação e repertório de mobilização no MDB nos anos 70", de Eliana Tavares dos Reis (sob orientação de Celi Regina Jardim Pinto). Adelmo Genro Filho foi presidente do Setor Jovem do MDB de Santa Maria de 1974-1975, sendo depois substituído por Sergio Weigert (REIS, 2001, p. 119-120).

5 O jornal a que Herz faz referência aqui é o "Jornal Informação", com sede em Porto Alegre.

6 As eleições ocorreram em 15 de novembro de 1976. Genro Filho foi o segundo vereador mais votado de Santa Maria, com 2321 votos, e seu mandato foi de 1977 a 1982 (REIS, 2001, p. 128).

7 Maria Rita Assis Brasil era estudante de medicina da UFSM quando foi eleita a $11^{\text {a }}$ vereadora mais votada daquela legislatura, com 1121 votos. Ela era esposa de Sergio Weigert nesse período e os dois eram amigos muito próximos de Adelmo Genro Filho e de sua então esposa, Letícia Pasqualini. Atualmente, Maria Rita Assis Brasil trabalha como médica em Porto Alegre e é vice-presidente do Sindicato Médico do Rio Grande do Sul (SIMERS).

8 Marcos Klassmann era líder do Setor Jovem Metropolitano do MDB e tinha no jornal informação uma espécie de comitê de campanha. De acordo com Reis (2001), foi eleito surpreendentemente para vereador em Porto Alegre com 12.118 votos. Seu slogan de campanha era "Vote contra o Governo". Em 09 de fevereiro de 1977, teve seu mandato cassado devido a seu discurso de posse como líder do MDB na Câmara. Ele passou a ser um símbolo da resistência e da luta pela anistia política no Rio Grande do Sul. Recuperou o mandato apenas em 1979 e exerceu-o até 1982. Posteriormente, filiou-se ao PDT e depois ao PT. Faleceu em 03 de janeiro de 2005. 
pretendia ter uma qualidade jornalística. A experiência do "Semanário Informação" foi muito interessante, porque ele foi, dos jornais regionais da imprensa alternativa, o único que teve maior duração e com um caráter semanal. Nós duramos cerca de 28 semanas, ou seja, quase meio ano. O projeto era para durar seis meses. Se possível continuar, mas o projeto básico era de seis meses. E era um jornal mantido semanalmente, mesmo com todas as dificuldades.

Nós nos deparamos com essa realidade concreta: nós não sabemos fazer jornal. Temos recursos. Limitados, mas temos recursos. Temos amparo político, uma sustentação expressiva. Mas não conseguimos traduzir isso em projeto para um jornal. Bom, essa é uma história a parte, que mereceria até uma discussão, mas nós vamos ficar por aqui com esse registro da dificuldade de traduzir consequentemente no plano da atividade jornalística, um projeto político.

As discussões nesse período avançaram muito pouco. Predominou fundamentalmente durante toda a experiência do jornal um empirismo. Apesar disso, em algumas matérias desse jornal, folhando hoje, localizam-se certos embriões, certas experiências, protótipos que eram resultados das discussões que se levava e que podemos identificar certas experiências do que se fazia ali com as concepções que depois vão aparecer claramente formuladas em O Segredo da Pirâmide. Mas, é uma fase ainda puramente empírica.

Em 1977, Adelmo publica artigos, principalmente no "Diário de Notícias" de Porto Alegre e no "A Razão" de Santa Maria onde, aí sim, já está claramente formado o embrião do que seria a chave de sua abordagem do jornalismo, a questão da singularidade como categoria central de uma teoria do jornalismo ${ }^{10}$.

9 Pelo contexto da fala, trata-se do Jornal Informação de Porto Alegre.

10 Desses textos foram publicados pela revista de Estudos em Jornalismo e Mídia da UFSC: "O Jornalismo e a Crise da objetividade burguesa" (publicado originalmente no "Diário de Notícias" de Porto Alegre em 27 de julho de 1975), "Questões sobre Jornalismo e Ideologia" (publicado no "A Razão" de Santa Maria em 22 de outubro de 1977) e "Sobre a necessidade de uma teoria do jornalismo" (também publicado no "A Razão"). 
Em 1978, participei junto com Adelmo da decisão de fazer mestrado. Ele já estava há dois anos na Câmara dos Vereadores de Santa Maria. As perspectivas políticas não eram muito significativas. Não se previa nada muito importante no horizonte político do Brasil. E Adelmo já tinha - e aqui insisto nesse aspecto do depoimento bastante claro a importância da teoria e da necessidade extrema que se tem de fundir teoria e prática. Ou seja, da atividade política estar informada, estar amparada em uma sólida formação teórica.

Decidimos então fazer o mestrado em Brasília. Fomos fazer esse concurso - e eu faço questão de fazer esse registro aqui porque é um aspecto do currículo de Adelmo que merece esclarecimento. Nesse concurso na Universidade de Brasília, chegamos lá e depois - a história foi sendo reconstituída depois - descobrimos que havia apenas duas vagas. Isso porque das sete ou oito vagas disponíveis, as outras seis já estavam destinadas. Havia uma vaga que era para o candidato do Banco do Brasil. Havia outra vaga que estava destinada para uma afilhada de um promissor político do Maranhão chamado José Sarney. Assim, as vagas estavam todas destinadas. E a banca - isso, como eu disse, só foi reconstituído depois - resolveu que não daria as vagas para duas pessoas do Rio Grande do Sul. Dois jornalistas do Rio Grande do Sul. E escolheram um deles. Aquele que eles acharam que viria para Brasília. Eles acharam que Adelmo, um vereador em pleno mandato, acabaria não indo para Brasília. E aí distribuíram a outra vaga, com outros critérios.

Então, Adelmo foi reprovado nesse concurso em Brasília. Mas a reprovação não tem nenhuma relação com o mérito da avaliação, meramente política. E, até hoje, eu sei de pessoas do mestrado em Comunicação de Brasília que se arrependem desta decisão de caráter estritamente político. E assim foi retardada a entrada de Adelmo na área acadêmica. 
Eu acabei fazendo o mestrado em Brasília em 1979. Lá conheci César ${ }^{11}$ e Lanzetta $^{12}$ e acabei fazendo o concurso aqui. O que mais tarde ajudou também a aproximar Adelmo e a estimulá-lo a vir engrossar fileiras em um grupo que demonstrava boas perspectivas de trabalho.

Adelmo segue a trajetória dele ${ }^{13}$. Em 1981, publica o livro, juntamente com Sergio Weigert e Marcos Rolim, "Hora do Povo: uma vertente para o fascismo". Um livro que funde uma análise política com algumas questões específicas do jornalismo. Mas que levanta questões importantes que serão tratadas e incorporadas no livro "O Segredo da Pirâmide".

Em 1982, Adelmo concorre a deputado estadual. Não foi eleito. Acho que a fraude eleitoral definiu aquelas eleições. E para Adelmo faltaram dois, três mil votos para eleição, muito pouco. Com a derrota nas eleições, Adelmo presta concurso aqui e, em 1983, ingressa na Universidade Federal de Santa Catarina. Em 1985, ele começa o mestrado $^{14}$. E a tese dele é justamente sobre o jornalismo. Em 1987, essa tese, concluída no final de 1986, é adaptada em mínimos detalhes e publicada com esse título "O Segredo da Pirâmide" ${ }^{15}$.

Foi esse conjunto de características que resultou nessa obra específica " $\mathrm{O}$ Segredo da Pirâmide". Sem essas circunstâncias, que revelam até alguma acidentalidade, talvez não tivéssemos esse trabalho hoje. Essas circunstâncias de certa forma alteraram as prioridades de Adelmo e o leque de interesses dele,

11 Trata-se de Cesar Orlando Valente, jornalista e professor que participou da comissão de criação do então curso de Comunicação Social/ Jornalismo da UFSC. Lecionou na UFSC de 1979 a 1994.

12 Luiz Ricardo Lanzetta foi professor do Departamento de Comunicação Social/ Jornalismo da UFSC de 1979 a 1986. Os três cursaram mestrado em Comunicação na UnB.

13 Conforme declarações de Pedro Osório (2007, p. 38), Genro Filho também teria tentado acesso ao mestrado em Filosofia na UFSM, provavelmente em 1980 (Osório usa a expressão "se a memória não me trai" para se referir ao ano).

14 Nesse momento da palestra, Herz chega a perguntar para a mesa se a entrada de Genro Filho no mestrado em Ciências Sociais ocorreu mesmo em 1985. Segundo registros do Programa de Ciências Sociais da UFSC, ele ingressa no mestrado em 1984 e apresenta sua dissertação em 24 de abril de 1987. 15 É possível que a menção de Herz ao ano de 1986 seja à data da conclusão do texto da dissertação. O título do livro é o mesmo da versão final da dissertação entregue no Programa de Pós-Graduação em Ciências Sociais. Porém, de acordo com o editor do livro, Luiz Carlos Tau Golin, em entrevista concedida no dia 23 de julho de 2013 para minha tese, o título do manuscrito entregue para revisão e edição do livro não era esse. Foi decidido para a publicação e depois estendido por Genro Filho ao titulo da dissertação. 
progressivamente centrado na filosofia. Apesar do interesse no jornalismo ser um interesse subsidiário importante, das experiências concretas que ele viveu e da necessidade premente de uma teoria do jornalismo, sem dúvida a vinda dele para a UFSC foi decisiva para o resultado deste trabalho. Particularmente, sinto-me muito satisfeito por ter insistido muito para que o tema da tese de Adelmo representasse esse acerto de contas com a área da Comunicação. E eu acho o resultado do trabalho expressivo, o que destacaremos a seguir.

\section{II}

Por ser uma obra mais acabada, por ser, talvez, a obra mais acabada de Adelmo, "O Segredo da Pirâmide" tem importância multiplicada. Por dois aspectos. Em primeiro lugar, pela originalidade da abordagem. É realmente uma análise muito original dentro das abordagens tradicionais do marxismo. Não só em relação ao objeto jornalismo pois aí o marxismo não apresenta respostas -, mas frente a abordagens do marxismo a objetos específicos em diversos campos do conhecimento. Em segundo lugar, por traduzir a inflexão desse marxismo antidogmático que marcou o trabalho de Adelmo. Portanto, é uma obra importante também por explicitar de forma muito clara as principais concepções filosóficas e ideológicas de Adelmo. É uma obra muito rica, muito densa.

Talvez eu seja a pessoa que tenha a lido mais vezes. Eu li quando trabalhei na correção da dissertação de mestrado e na fase que antecedeu a publicação do livro. E li depois. Eu já li seis vezes esse trabalho. E apesar de ter lido todo esse número de vezes - o que me credencia a acreditar que eu seja a pessoa que tenha mais intimidade com o texto -, sempre aparece algo novo. Sempre aparece algum detalhe que passou despercebido, uma nuance, uma inflexão que abre caminhos novos, possibilidades novas de desdobramentos. É uma obra muito densa. Não há nada supérfluo, não há nada casual. Tudo ali dentro está encaixado, tem um sentido e reflete o conjunto de construções de Adelmo. 
Essa obra, para fazer uma síntese, poderia ser lida de muitas maneiras. Como esse seminário se propõe a tratar dos aspectos de sua obra política e filosófica, vou me concentrar nas suas concepções sobre o jornalismo. Faço isso acreditando também que o público predominante aqui é o de jornalismo. Porém, destaco que o conjunto da obra de Adelmo tende a constituir um sistema. Ele tem certa organicidade. Embora muitas temáticas permaneçam embrionárias, ela tende a um fechamento, a uma coerência interna. Por isso, eu acho que mesmo tratando especificamente do objeto jornalismo, talvez seja preciso fazer os nexos à abordagem política e filosófica que o seminário proporcionará $^{16}$.

Optamos por sintetizar a obra com base na transcrição de uma palestra do próprio Adelmo, em um seminário realizado ano passado na PUC de Porto Alegre para estudantes de comunicação ${ }^{17}$. Nessa palestra, ele expõe sua abordagem do livro. E eu acho que, assim como não cabe qualquer tipo de culto à memória de Adelmo - o que no caso de Adelmo até soaria redobradamente ridículo, dado o sentido crítico que ele próprio sempre exerceu sobre o que estava estabelecido -, também não cabe uma simplificação do que ele acumulou particularmente nessa obra. Por isso, essa opção em reproduzir sua própria expressão feita em palestra pretende também adotar a simplificação que ele próprio admitiu fazer. Portanto, vou procurar recuperar a expressão de Adelmo. Não ser um tradutor do pensamento dele, mas um mero portador dessa abordagem na forma como o próprio Adelmo pessoalmente expôs o tema para os estudantes de comunicação.

Para buscar uma teoria do jornalismo, ele teve que entrar em terreno virgem, inexplorado, porque até agora não se impôs uma concepção teórica satisfatória sobre o jornalismo especificamente ${ }^{18}$. Adelmo, nessa palestra, começa colocando uma premissa

16 Trata-se das palestras "Adelmo Genro Filho e a Política" e "Adelmo Genro Filho e a Filosofia", que, com a palestra de Herz, compõem o evento em homenagem a Genro Filho.

17 A palestra de Genro Filho foi realizada no Encontro Regional de Estudantes de Comunicação (ERECOM), em junho de 1987, na PUC-RS, em Porto Alegre.

18 A partir desse trecho, a exposição de Herz é a reprodução da palestra realizada por Adelmo Genro Filho. Essa palestra foi publicada pelo jornal laboratório Zero (UFSC) em 1989 (GENRO FILHO, 1989), pela FENAJ em 1996 e teve nova publicação em 2007 no livro "Olhares sobre o Jornalismo: A 
básica sobre a teoria. O que é teoria? Nós podemos dividir as formas de conhecimento humano, para efeito dessa situação, fazendo uma simplificação de duas maneiras: de um lado o conhecimento empírico, o conhecimento pragmático, conhecimento de dia a dia, conhecimento de senso comum - tomando todas essas expressões como sinônimas; e de outro, o conhecimento teórico.

O conhecimento empírico, do dia a dia, é aquele que obedece a uma observação particular, limitada. Constata a existência de fenômenos e, a partir daí, digamos assim, formula esse conhecimento através do discurso, mas sem uma generalização, sem uma universalização do significado daquele fenômeno. Por exemplo, a maneira diferente pela qual um físico abordaria determinado fenômeno natural, o fato de jogar essa caneta para cima e a caneta cair $^{19}$. Esse fenômeno pode ser objeto de dois tipos de conhecimento: um, o conhecimento pragmático, o conhecimento que pode dizer o seguinte: "olha, as canetas jogadas para cima caem". Ou, um conhecimento ainda pragmático, embora mais geral, que poderia dizer o seguinte: "as coisas, quando jogadas para o ar, caem". Mas, nós também podemos fazer uma formulação rigorosamente universal sobre esse fenômeno. Podemos dizer alguma coisa assim como: "matéria atrai matéria na razão direta das massas e na razão inversa do quadrado das distâncias".

Contribuição de Adelmo Genro Filho", organizado por Márcia Franz Amaral (GENRO FILHO, 2007). No momento da exposição de Herz, a transcrição da palestra de Adelmo Genro Filho circulava apenas entre alguns estudantes e professores do curso de Comunicação Social/ Jornalismo da UFSC. A leitura pública da transcrição era inédita na circunstância da palestra de Herz. Serão sinalizados em notas os momentos de alteração, supressão ou omissão de trechos da palestra de Genro Filho na de Herz. Para esse cotejamento, será utilizada uma versão da transcrição da referida palestra datilografada em 1987 , sem título, gentilmente fornecida pelo professor Samuel Pantoja Lima e que era muito parecida com a que Herz utilizava (GENRO FILHO, 1987b). Simultaneamente, há o cotejamento com o áudio da palestra de Genro Filho, gentilmente compartilhado pelo professor Francisco José Karam (GENRO FILHO, 1987a). Também, cotejamos com duas versões publicadas da palestra: a primeira sob o título "O Jornalismo já tem sua teoria", publicada no Caderno Especial Z, do jornal Zero na edição de setembro de 1989; e segunda publicada sob o título: "O Segredo da Pirâmide: para uma teoria marxista do jornalismo", em 2007. Esse embasamento no documento fornecido por Pantoja Lima acontece porque algumas expressões e exemplos de Genro Filho, presentes na transcrição e no áudio, mas suprimidas nas versões publicadas, são lidas por Herz. Por outro lado, são perceptíveis algumas correções já presentes nessa primeira transcrição em relação ao áudio e que estão presentes na fala de Herz.

19 Na palestra, Genro Filho utiliza "um jornal” para exemplificar o raciocínio. As versões publicadas em 1989 e 2007 da palestra utilizam "uma pedra". Por sua vez, Herz usa "uma caneta". 
Então, vejam bem, eu formulei a essência desse fenômeno através de uma universalização máxima, uma universalização rigorosa que explicita a essência de todos os acontecimentos dessa ordem de objetos que são jogados para cima e que são atraídos, então, por massas maiores ${ }^{20}$.

Bom, a teoria é importante, indispensável, porque só a teoria oferece um tipo de conhecimento profundo capaz de direcionar a prática. A visão que nós temos, a visão comum, a visão vulgar que nós temos sobre a teoria é de que a teoria na prática é outra. Mas isso é uma falácia.

$\mathrm{Na}$ verdade, é na prática que a teoria comprova sua efetividade e a sua realidade. Isso se for uma teoria correta, se for uma boa teoria, se for uma teoria que corresponda, efetivamente, à essência dos fenômenos. Então, a única maneira de captar a essência das coisas é através de uma apreensão teórica, uma apreensão da universalidade do fenômeno, daquilo que ele tem de essencial e de genérico, que é subjacente ao fato observado.

Como é que se chega à teoria? Chegar à teoria ou chegar ao conhecimento científico é um percurso muito árduo, exige um esforço. Esforço até mesmo físico. É preciso conhecer pelo menos uma parte de todo conhecimento acumulado na área que queremos abordar. E é necessário um esforço de reflexão e de criatividade para apanhar essa realidade que não aparece à primeira vista, que não aparece aos olhos ${ }^{21}$. As coisas

20 Herz suprime aqui o trecho: "Embora, segundo a teoria da relatividade, essa lei esteja inclusive ultrapassada. Há outra explicação da gravidade, segundo a teoria da relatividade. Mas não é o nosso campo".

21 Herz altera parcialmente o trecho original. Na transcrição da palestra, o trecho original é "[...] exige um esforço, até físico, para abordar e para conhecer pelo menos uma parte de todo o conhecimento acumulado e um esforço de reflexão e de criatividade para apanhar essas realidades que não aparecem à primeira vista, que não aparecem aos olhos" (GENRO FILHO, 1987b, p. 3). Nas versões publicadas, há algumas diferenças que alteram parte do sentido da frase: "[...] exige um esforço, até físico. Para abordar e para conhecer pelo menos uma parte de todo o conhecimento acumulado e um esforço de reflexão e de criatividade para apanhar essas realidades [...] (GENRO FILHO, 1989, p. Z1); "[...] exige um esforço, até físico. Para abordar e para conhecer pelo menos uma parte de todo o conhecimento acumulado, é necessário um esforço de reflexão e de criatividade para apanhar essas realidades [...]" (GENRO FILHO, 2007, p. 81 - destaque nosso para a diferença em relação à versão publicada em 1989). O áudio pode ser transcrito da seguinte forma: “[...] exige um esforço até físico para abordar e para conhecer pelo menos uma boa parte de todo o conhecimento acumulado e um esforço de reflexão e 
que aparecem aos olhos - e o Adelmo parafraseia Saint Exupéry - não são coisas essenciais. O essencial é realmente, como diz Saint Exupéry ${ }^{22}$, invisível aos olhos. Se nós tomarmos essa frase metida à poética e a interpretarmos no sentido epistemológico, nós vamos ver que ele tem absoluta razão. O essencial não aparece aos olhos.

Por exemplo, o que é essencial no modo de produção capitalista? O essencial no modo de produção capitalista é a produção de mercadorias. Isso é o que define o modo de produção capitalista como sistema. Mercadoria é uma coisa que fora da relação conceitual não aparece. Mercadoria, portanto, é uma relação social concreta. Então, se formos olhar, da janela do nosso edifício, o capitalismo, tudo o que nós estamos vendo não é essencial. São coisas, fenômenos, coisas que aparecem. Nós só podemos captar a essência desse modo de produção se nós abordarmos esse modo de produção teoricamente e captarmos aquilo que não aparece, ou seja, como internamente ele funciona. Esse é o trajeto, essa é a finalidade da teoria.

O jornalismo se encontra em um impasse teórico ${ }^{23}$. Porque, grosso modo, as abordagens que nós temos sobre o jornalismo caem em alguns extremos que, de algum modo, não perfazem o caminho da teoria. O caminho da teoria é o que leva ao concreto. Não é o caminho da observação empírica, fenomênica, que leva ao concreto. O próprio concreto não aparece aos olhos, o que aparece é a superfície do concreto. O concreto é aquilo que é apanhado na sua essência.

As definições que nós temos de jornalismo poderiam ser sintetizadas, hoje, em três versões, para efeito dessa discussão, já que não dá para fazer uma exposição de todos os subcaminhos que a teoria do jornalismo ${ }^{24}$ toma, nós vamos sintetizar em três

de criatividade para apanhar essas realidades que não aparecem à primeira vista, que não aparecem aos olhos" (GENRO FILHO, 1987a - destaque para a única palavra diferente em relação à transcrição sem revisão utilizada para cotejamento).

22 Há a adição por Herz do trecho "[...] realmente, como diz Saint Exupéry [...]”.

23 Supressão da frase de Genro Filho que viria a seguir: "E falo do jornalismo aqui no sentido mais restrito do que é a comunicação em geral" (GENRO FILHO, 2007, p. 82).

24 Herz diz aqui teoria do jornalismo. Em todas as versões cotejadas da palestra de Genro Filho a expressão "teoria do jornalismo" não aparece. A frase em Genro Filho (1989) está truncada, mas a menção é "aos subcaminhos teóricos" que são tomados na discussão do jornalismo. Essa estrutura é levemente modificada na versão publicada em 2007, mas permanecem essas mesmas palavras. No mais, 
principais abordagens. Primeira delas: uma forma de considerar o jornalismo é sob o ponto de vista de uma generalidade abstrata. Vejam bem, se nós dissermos, por exemplo, o jornalismo é uma forma de comunicação. Isso é verdade. Ninguém tem dúvida que o jornalismo é uma forma de comunicação. Isso é uma realidade universal. Mas será que isso é teórico? Teórico no sentido de apanhar o concreto? A resposta é óbvia: não é! ${ }^{25}$ Porque somente capta a generalidade, não capta aquilo que é específico do jornalismo. Essa frase é tão grandiosa, é tão importante quanto dizermos, por exemplo, que João ou que fulano de tal é ser humano ${ }^{26}$.

Se vocês perguntarem a fulano, ou João ${ }^{27}$, quem é ele, se nós respondermos "é um ser humano", nós vamos coincidir com dados sensíveis da realidade. Mas, essa generalidade que abstrai as particularidades e as singularidades desse sujeito, ou desse objeto da nossa abordagem, ela não capta mais do que a generalidade. Não contém nenhum traço, nenhum aspecto de especificidade ${ }^{28}$. Então, dizer que o jornalismo é uma forma de comunicação não nos diz nada especificamente sobre o jornalismo. É uma obviedade elementar. E algumas das abordagens que esse formalismo produz parte dessa definição: "o jornalismo é uma forma de comunicação", sem chegar a lugar nenhum.

Em segundo lugar, uma segunda abordagem muito comum sobre o jornalismo, é o da tradição mais filiada ao positivismo e ao funcionalismo. Quando nós encontramos

toda a frase em Herz guarda o mesmo sentido do da palestra de Genro Filho, mas está construída de modo diferente.

25 No áudio da palestra essa entonação não existe. Genro filho diz "Teórico no sentido de apanhar o concreto? Não é, porque só capta a generalidade, mas não capta aquilo que é específico do jornalismo". A entonação da fala não sugere exclamação. Porém, tanto a transcrição, como a versão lida por Herz e as versões publicadas trazem a ênfase. Herz adiciona ainda o trecho "A resposta é óbvia".

26 Herz suprime um parágrafo em que Genro Filho traz o exemplo de Klaus Barbie para explicar outro sentido da atribuição "humano". Ver Genro Filho (2007, p. 82-83).

27 Genro Filho cita Luciano ao invés de João. Trata-se de um estudante da UFSC, Luciano de Faria. Isso demonstra que a versão lida por Herz já traz modificações em relação à transcrição que estamos cotejando. O nome João permanece nas versões publicadas, o que sugere que a transcrição lida por Herz já era mais elaborada.

28 Essas três frases foram reelaborações de Herz de trecho similar da palestra de Genro Filho (2007, p. 83). Situação que se evidencia devido às hesitações presentes na fala de Herz, o que é natural em comunicações dessa natureza. As frases mais demarcadas e definidas retornam com a leitura do texto de Genro Filho, o que acontece a seguir. 
alguns conceitos que dizem mais ou menos assim: “jornalismo é uma forma de comunicação que serve para integrar e adaptar o homem ao seu papel social". Observem que com essa definição, nós avançamos um pouco. Nós retraímos a generalidade e atribuímos então o fato de que o jornalismo não é uma forma de conhecimento qualquer, não é uma forma de comunicação qualquer. Mas é uma forma de conhecimento, de comunicação, que serve para integrar o homem, para que ele funcione dentro do sistema ao qual ele pertence. Então, nós avançamos um pouco, mas ainda não chegamos ao concreto. Por quê? Porque o jornalismo, ele de fato, também é uma forma de educar e de situar o homem no seu papel social e na sua função definida pela sociedade. Mas isso nós podemos observar também genericamente, também superficialmente.

A pergunta que fica é a seguinte: será que o jornalismo é só isso? Será que o jornalismo é exclusivamente uma forma de integração do indivíduo no papel que a sociedade lhe atribui? Ou o jornalismo teria uma potencialidade a mais? Além de ser isso, ele teria algo mais, responde Adelmo. Uma potencialidade que transpassa, que transgride esse limite de uma mera integração funcional do indivíduo na sociedade.

Uma terceira forma de abordar o jornalismo, essa adquirindo um sentido crítico, limita-se a uma crítica meramente ideológica que diz mais ou menos assim: jornalismo é uma forma de comunicação que serve para reforçar a hegemonia ideológica da burguesia e reproduzir a dominação de classe. O que também é uma verdade. $O$ jornalismo, exatamente, faz essa integração com esse sentido, em seu papel positivo, ou seja, no papel social dado, no papel que a sociedade lhe oferece. Agora, se nós formos analisar isso do ponto de vista crítico, percebemos que o jornalismo faz com que as pessoas funcionem regularmente com a função que a sociedade de classe lhe atribui. Portanto, o jornalismo é realmente um instrumento de reforço da ordem vigente, que é uma ordem burguesa, capitalista. É uma ordem dada por uma sociedade de classe.

Mas, ainda sim fica uma pergunta: será que o jornalismo é exclusivamente uma forma de dominação? Que se isso for correto, nós tiraríamos a seguinte conclusão: o dia que conseguirmos fazer refluir, acabar com essa forma de dominação burguesa, e 
mesmo, não só a dominação burguesa, como qualquer forma de exploração do homem pelo homem, consequentemente, sendo o jornalismo uma forma de dominação, vai acabar o jornalismo. Essa é uma conclusão que se impõe em várias vertentes marxistas ao abordar o jornalismo ${ }^{29}$. É uma conclusão que se impõe e que reduz o jornalismo a uma das funções que ele tem na sociedade de classe, do ponto de vista do interesse dominante. Então, o jornalismo é isso também. O jornalismo é um instrumento de reprodução dos conceitos, das ideias, da ética, enfim, da ideologia dominante. Perpassa através do exercício do jornalismo, de um modo dominante, de um modo preponderante hoje numa visão de mundo que é uma visão de eternidade, de permanência do mundo burguês, ao qual nós estamos de uma forma ou de outra, ligados ${ }^{30}$.

Mas vejamos o seguinte, que é o caminho tradicional, o caminho de se partir de um conceito de jornalismo, e nos posicionarmos em relação a essas três abordagens: a primeira do senso comum, da generalidade abstrata; a segunda do positivismo/ funcionalismo, do jornalismo com o papel de integração; e a terceira de uma análise crítica, muitas vezes de tradição marxista, em que se atribui ao jornalismo uma mera reprodução da ideologia burguesa. Diante dessas três vertentes inadequadas, procura-se uma base de conceituação ${ }^{31}$. O caminho tradicional é o que parte de um conceito de jornalismo. Aliás, o que se faz em boa parte da ciência. A partir desse conceito, se eleva um edifício conceitual, tentando chegar a uma conclusão. Isso geralmente leva a caminhos falsos. E as tentativas que se fez por essa via de confrontar essas correntes do jornalismo não saíram muito de seus horizontes. Porque quando parto de um conceito já dado de jornalismo, que de certa forma seria um conceito que deveríamos querer no final dessa trajetória, nós acabamos condicionando a abordagem.

29 Essa frase não consta na palestra de Genro Filho.

30 A versão publicada pelo Zero (GENRO FILHO, 1989a, p. Z2) exclui esta última frase, que está também presente na transcrição e no áudio que cotejamos. A versão publicada em livro (GENRO FILHO, 2007 , p. 85) segue a versão do Zero e também não traz a frase.

$31 \mathrm{O}$ início do parágrafo até esse ponto não consta na palestra de Genro Filho, sendo, portanto, uma estratégia de exposição de Herz. Inicio que modifica em algumas palavras as frases seguintes em relação à palestra de Genro Filho, o que, por sua vez, não altera em quase nada o conteúdo e os conceitos expostos originalmente. 
E eu acho que foi essa uma das principais digressões do método de investigação do jornalismo, que Adelmo inverteu, e que permitiu as conclusões a que ele chegou. Aliás, essa é uma das características desse aspecto recorrente do método de abordagem com o qual ele conduz o pensamento, não só na área do jornalismo, mas em várias outras aplicações da filosofia.

Adelmo propõe, e acho que esse é um dos caminhos novos criados por esse livro, que na abordagem de uma temática nova, no caso de uma abordagem para o jornalismo, não se pode partir senão de um conceito provisório, de um conceito que terá que ser comprovado e ampliado ao longo do desenvolvimento e da discussão. Quer dizer, ele não apresenta imediatamente uma visão teórica, um conceito completo, uma visão teórica fechada. Ele parte de um conceito e desenvolve o restante do raciocínio sobre esse conceito. Porque o conceito final do jornalismo será o resultado dessa trajetória, desse esforço, desse percurso teórico ${ }^{32}$.

Então, nessa exposição aqui, que estou procurando reproduzir, ele repete isso. Ele parte do contexto das abordagens sobre o jornalismo e diz o seguinte: olha, nós vamos recompor uma abordagem teórica sobre o jornalismo a partir de um conceito bem elementar e vamos trilhando nesse contexto teórico que temos aí e vamos chegar a um conceito complexo, rico, que é o resultado da trajetória, o resultado do esforço que vamos fazer ao longo desse percurso teórico. Vamos nos confrontar com essas três vertentes da abordagem sobre o jornalismo.

O conceito provisório que ele parte é o de tratar o jornalismo como uma forma social de conhecimento. Ele reconhece que se trata de um conceito provisório. De um ponto de partida. E de que esse ponto inicial não é muito mais do que uma generalidade abstrata. Até porque existem outras formas sociais de conhecimento, de comunicação, que também implicam nesse conhecimento. Poderíamos citar, por exemplo, a arte. Poderíamos citar a ciência, que também é uma forma que funciona socialmente e que

32 Nesse parágrafo, Herz substitui a leitura de Genro Filho (2007, p. 85) por uma explicação do que este diz. Essa estratégia permanece nos próximos parágrafos. 
implica em uma apropriação de conhecimento. Não só apropriação, significa também produção e apropriação de conhecimento. Então, Adelmo parte reconhecendo a debilidade inicial desse conceito. Porque o que interessa é concretizar o conceito ao longo da exposição ${ }^{33}$. Vamos partir da ideia de que o jornalismo é uma forma social de conhecimento. Lembrando que isso é genérico e que a arte e a ciência também são. E vamos tentar diferenciar o jornalismo, ou seja, buscar agora a especificidade do jornalismo como forma social de conhecimento.

Mas para isso é preciso discutir alguma coisa de filosofia, senão não será possível chegarmos a um conceito mais concreto. Porque nós temos que subir aos ramos mais abstratos do saber, a filosofia, para podermos chegar ao concreto. E, ao contrário do que pensa o senso comum, de que as reflexões abstratas são um caminho sem retorno para a vida, Adelmo ressalta, não só nessa obra como em muitos momentos, que elas podem ser sem retorno - podemos fazer uma filosofia, uma teorização que se perde em uma lógica abstrata. Aí teremos a lógica abstrata já referida anteriormente. De qualquer maneira, para se chegar ao concreto, precisamos chegar a esses níveis mais abstratos para depois retornar ao conhecimento concreto. Apreender, fazer o trabalho de retorno dessas categorias ao concreto. Categorias que são conceitos amplos de qualquer teoria, de qualquer ciência.

Para buscar esse conceito, para buscar essa definição de jornalismo, são utilizadas categorias de alta tradição na filosofia clássica, especialmente na filosofia clássica alemã, fundamentalmente em Hegel: as categorias do singular, do particular e do universal. Gostaria que vocês observassem como essas categorias se agregam e compõem indissoluvelmente o conceito final de jornalismo que Adelmo propõe como resultado final desse trabalho ${ }^{34}$.

Sobre essas três categorias, nós podemos fazer algumas afirmações: a) essas três categorias são dimensões reais e objetivas do mundo. E nessa exposição, Adelmo

33 A partir desse ponto ele retorna a seguir a transcrição da palestra de Genro Filho.

34 Essa última frase é uma intervenção de Herz para destacar a importância do que vem a seguir. 
procura provar que as categorias de singular, particular e universal não são uma abstração da cabeça do Hegel ou mesmo da filosofia clássica alemã. São conceitos que representam formas objetivas da existência das coisas no mundo. O primeiro é o singular $^{35}$. Como singular nós podemos tomar Eduardo ${ }^{36}$. Eduardo é um ser, um objeto do mundo singular. É aquilo que não se repete, aquilo que é idêntico só a si mesmo. Eduardo tem todas as características físicas, de temperamento, de personalidade que definem uma pessoa absolutamente singular. Não existe ninguém que seja igual a ele no mundo. Ele é resultado de uma série de condições que produzem esse sujeito singular. Mas, Eduardo também é um sujeito particular e universal. Então eu diria o seguinte: Eduardo faz parte do círculo de pessoas que usam óculos, ou que não fumam. Essa qualificação contém particularidades que definem a inserção dele em grupos maiores, em que existem elementos de densidade do Eduardo com outros indivíduos, compondo relações de diferenciação e de identidade. Eduardo faz parte das pessoas que não fumam. Dos professores de comunicação. Dos jornalistas. A partir dele poderíamos qualificar várias particularidades.

Bom, já identificamos aqui características de singularidade e de particularidade de Eduardo. Vamos tentar demonstrar que Eduardo também é universal. Eu perguntaria se é errado ou é correto afirmar que Eduardo é um ser humano? É correto. Essa é uma característica essencial, o fato de ser humano, o fato de pertencer a essa categoria universal dos seres humanos. Então, nós vimos como identificar em Eduardo a singularidade, a particularidade e a universalidade ${ }^{37}$.

Assim, nós vamos chamar atenção para o segundo aspecto sobre essas três categorias. Essas três características de Eduardo existem sempre em uma relação

35 A partir desse trecho, a explicação de Herz é uma adaptação livre da palestra de Genro Filho (2007, p. 87-90). Quando as diferenças de ideias tiverem maior relevo, serão assinaladas.

$36 \mathrm{O}$ Eduardo referenciado por Herz é Eduardo Meditsch, que compunha a mesa do evento. Na palestra, Genro Filho volta a mencionar "Luciano" e nos textos publicados (1989; 2007) consta "João".

37 Como Herz segue na adaptação da explicação de Genro Filho, importante mencionar que ele suprime um parágrafo: "Então, todas as coisas no mundo, no universo, existem pelo menos em três dimensões: o singular, o particular e o universal. Isso é um pressuposto essencial para discutirmos mais adiante o jornalismo" (GENRO FILHO, 1989, p. Z2; 2007, p. 88). 
determinada entre si. Ou seja, o particular é sempre particular em relação a um singular e em relação ao universal. Ele não é particular por si mesmo. Vamos tentar explicar essa relação que grosseiramente poderíamos chamar de dialética. Por que isso? Porque eu posso partir de diversas possibilidades de conexão de estabelecimento da relação de singularidade, particularidade e universalidade. A singularidade de Eduardo pode ser referida à particularidade de ser brasileiro e à universalidade de ser latino americano. A relação de conceitos, as categorias de particular, singular e universal, para adquirir sentido e para adquirir concreticidade, que nós estabelecemos a vinculação indissolúvel que há entre eles. Essas categorias não existem isoladamente, independentemente. É uma relação sempre amarrada, uma relação atada. Não existe o singular fixo. Até porque eu posso considerar todas essas possibilidades de variação ${ }^{38}$.

Uma terceira característica sobre essas três categorias que nós temos que destacar é de que sempre, em cada uma das dimensões, estão presentes as demais. Essa terceira afirmação sobre essas categorias é fundamental para a nossa distinção posterior do conceito de jornalismo. Significa que no conceito de universalidade, ou seja, de ser humano, nós todos estamos presentes. Se no universal estamos todos incluídos, significa que no universal estão contidos os somatórios das singularidades e particularidades. Agora, se nós olhamos do ângulo da particularidade ou da singularidade, podemos verificar que em cada uma dessas dimensões, as demais também estão presentes. Mas estão presentes de forma subjacente, de forma superada, como se estivessem dormidas, como se dissolvidas dentro das demais categorias ${ }^{39}$. Elas não só se relacionam entre si dialeticamente, permanentemente e formam um sistema, como em cada uma delas as demais estão presentes. Não existe singularidade pura em que não estejam presentes dentro dela a particularidade e a universalidade. E não existe universalidade pura sem que dentro dela não estejam todos os casos. Se eu cheguei à conclusão que "matéria

38 Herz usa essa frase para sintetizar o exemplo de Genro Filho (1989, p. Z2; 2007, p. 89) de que João pode ser universal, os órgãos particulares e as células singulares.

39 Ao modo como Herz constitui a explicação, a impressão é de que as demais categorias ficam adormecidas apenas quando se trata da singularidade e da particularidade. No entanto, cotejando com o expresso por Genro Filho (2007, p. 90), isso também acontece com a universalidade. 
atrai matéria na razão inversa das massas e etc.", é porque isso corresponde a todos os casos, de todas as experiências humanas que demonstram que os objetos caem. Todos os casos particulares e singulares estão ali.

Dentro dessas três características, nós podemos dar um passo adiante no conceito de jornalismo. Adelmo diz então, já em um nível de abstração, num nível de concretização mais elevada, que o jornalismo é uma forma social de conhecimento. Mas não de um conhecimento qualquer. E sim, de uma forma social de conhecimento centralizado $^{40}$ no singular. Vejam bem, o conhecido pode ser cristalizado, pode se apresentar sob a forma de universal. Se alguém me diz uma lei da química ou da física, trata-se de um conceito real, sobre o mundo real. Não obstante, está formulado universalmente. Então, ele se apropria, eu conheço o mundo através de uma formulação, de um conhecimento que se cristaliza no universal. A ciência é, por excelência, a forma de conhecimento baseada no universal. $\mathrm{O}$ que interessa à ciência? Interessa à ciência que Pedro, Carlos ou João, no caso da Sociologia, tomem determinada atitude? Não, isso não interessa. Interessa na medida em que essas atitudes caracterizam comportamentos de certos grupos sociais, ou de certos tipos de pessoas ou de certas práticas sociais que tomam determinadas atitudes. A generalização é a base da ciência. A universalização é a base da ciência.

Agora, que nós queremos defender é que o jornalismo é uma forma de conhecer o mundo que não tem base - vamos começar por exclusão - não tem base na universalidade. Ao contrário, é uma forma de conhecimento que se cristaliza no oposto da universalidade, que é uma singularidade.

É uma forma de conhecimento, o jornalismo, que surge historicamente com base no desenvolvimento das relações capitalistas, com base na indústria. Poderíamos dizer que o desenvolvimento das relações capitalistas, o fato de que com o capitalismo a sociedade tornou-se um único sistema universal, um sistema cambiante, um sistema

40 Herz retorna nesse parágrafo a seguir o mesmo texto presente na transcrição. Porém, cita "centralizada no singular", enquanto Genro Filho diz "cristalizada no singular". 
dinâmico. O capitalismo é, na verdade, o primeiro sistema da história humana que tornou a humanidade um gênero efetivamente interligado internacionalmente, mundialmente. $\mathrm{O}$ gênero humano é todo interdependente. Ele forma um sistema só. Esse é um aspecto bastante original da contribuição de Adelmo ${ }^{41}$ de examinar essa abordagem nas relações que isso tem para tomar a práxis como categoria central. É destacar que o capitalismo não é apenas mais um modo de produção. Ele é "o" modo de produção. $\mathrm{O}$ modo que reestabeleceu, que colocou a humanidade em um novo patamar. É, aliás, o imperialismo, que foi a chave para o desdobramento dessa universalização do mundo, que não obstante está posta e tem também seu caráter de progresso ${ }^{42}$. Não se trata aqui de defender, mas temos que reconhecer que no imperialismo e no colonialismo há um caráter de progresso. Um caráter que faz a humanidade avançar no sentido dessa universalização, dessa planetarização. É o capitalismo, portanto, que coloca pela primeira vez em choque o homem, a realidade humana, com a realidade da natureza, com o ser realmente universal, como o ser que estende sua intervenção sobre todo o planeta.

Esse sistema único, o capitalismo, que gerou a necessidade do jornalismo. Por quê? Porque antes da existência desse sistema, nós tínhamos um conhecimento genérico e universal sobre o mundo. Mas tínhamos o conhecimento fundamentalmente baseado no singular, sobre a realidade imediata. Por exemplo, a realidade de nossa casa, dos nossos vizinhos. Ou a realidade de uma aldeia, de um sujeito da Idade Média que não tinha maior conhecimento além dos limites de sua aldeia, muitas vezes do limite de sua residência ou de seu castelo. Atualmente, nós temos uma situação radicalmente distinta. Nós temos não só um conhecimento que nos coloca em linha direta com nossos vizinhos, com nossos espectros cada vez maiores de relações, mas também nos coloca

41 O comentário presente desde "Esse é um aspecto" até "[...] em um novo patamar" é de Herz e não está presente na palestra de Genro Filho.

42 Essas duas últimas frases são de Genro Filho. Depois deste ponto até o final do parágrafo, Herz assume o discurso, alterando o seguinte trecho do discurso de Genro Filho (1987a): "Evidentemente que eu não estou defendendo o colonialismo. Ao contrário. Mas essa universalização que a humanidade produziu - com base inclusive na violência, na expropriação, na exploração - mantém uma base hoje que é universal, que é, portanto, esse sistema único que a humanidade forma". 
em contato com todo mundo através de suas feições singulares. Nós vemos hoje o mundo acontecendo e mudando em sua imediaticidade, na sua manifestação específica, na sua manifestação superficial, na sua manifestação fenomênica. Nós vemos o mundo diariamente em seu processo de transformação ${ }^{43}$.

Há uma data dessas que é famosa no Brasil, de sua Proclamação da República, que levou de 30 a 40 dias para chegar no Rio Grande do Sul e em Santa Catarina. Então, observem a radicalidade da experiência de uma dinâmica social, na qual a Proclamação da República leva - eu não me lembro se é essa data mesmo, mas serve anedoticamente apenas - levou 30 a 40 dias para, no Rio Grande do Sul, tomarem conhecimento. E, na atualidade, nós ligamos a televisão e está lá o presidente da República ou um personagem nacional, como o presidente da CUT, ou seja lá quem for, fazendo uma declaração ao vivo para todo Brasil, assistida simultaneamente por 50, 60 milhões de brasileiros $^{44}$. A realidade engendrada pelo capitalismo e pelos modernos meios de comunicação coloca o mundo à disposição na sua imediaticidade. Embora essa imediaticidade revele basicamente $\mathrm{o}$ aspecto fenomênico dessa evolução da realidade ${ }^{45}$.

Temos um contato com essa humanidade universalizada, mas eu não tenho meios pessoais e individuais para me relacionar diretamente com esse mundo. Respondendo a essa necessidade que surgem mediações orgânicas específicas, que são os meios de comunicação ${ }^{46}$. É precisamente dessa necessidade que surge o jornalismo, como uma forma de conhecimento, que vai cumprir um papel semelhante ao papel que cumpre a percepção individual da singularidade do fenômeno. Só que agora é como se nós nos relacionássemos com toda a imediaticidade do mundo. $\mathrm{O}$ nosso mundo não é

43 Herz altera significativamente o sentido dado por Genro Filho na comparação entre os indivíduos hoje em sua realidade imediata e o sujeito da Idade Média. Na palestra, Genro Filho (1989, p. Z3; 2007, p. 9293) defende que o conhecimento direto que as pessoas mantêm com a vizinhança ou com a casa se assemelha ao daquelas que viviam na Idade Média. No entanto, com a expansão da região de interesse e interconexões de todas as partes do globo, os sujeitos não conseguem o acesso direto àquilo que interfere diretamente em suas vidas, precisando, por isso da mediação do jornalismo. Herz, por sua vez, diz que a vida dos sujeitos de hoje é completamente diferente da do homem da Idade Média, o que apenas em parte corresponde ao sentido que Genro Filho deu à comparação anedótica.

44 Esse exemplo é de Herz e não está na palestra de Genro Filho.

45 Nessa frase, Herz recupera nas próprias palavras a ideia de Genro Filho. A leitura do texto da palestra de Genro Filho retorna no parágrafo seguinte. 
mais aldeia, o nosso mundo é uma aldeia global - parafraseando McLuhan ${ }^{47}$. O nosso mundo é a totalidade do universo humano. Essa pré-condição histórica é essencial ao jornalismo. Era preciso que o mundo se tornasse único, interligado e dinâmico para que surgisse a necessidade concreta, objetiva de que as pessoas se relacionassem com o mundo de alguma forma semelhante com o modo que se relacionam pessoalmente com os acontecimentos do dia a dia. Assim como nós presenciamos e participamos de uma greve, assim como nós assistimos a um acidente, nós temos contato com o que está acontecendo no Oriente Médio, na América Central. Enfim, esses meios de comunicação nos colocam em linha direta com a universalidade da humanidade ${ }^{48}$.

Era preciso, por isso, que surgisse o jornalismo. E essa necessidade veio acompanhada também de uma base material. E até pode-se dizer, em parte, que ela gerou essa base material. Essa base material é a indústria. Se não houvesse o desenvolvimento da indústria, que é a base da própria universalização da universidade do desenvolvimento capitalista, não haveria a possibilidade do jornalismo, que inicialmente surgiu do jornal em sentido estrito, do jornal de papel. Na metade do século passado, os jornais de características mais ou menos modernas começam a surgir. Hoje, o jornalismo, entretanto, não é mais apenas aquilo que é comunicado através dos jornais. São ciclos do jornalismo que se aplica também aos demais meios, ao rádio, à televisão e a outros que ainda estão em desenvolvimento ${ }^{49}$.

46 Essa frase não consta na palestra de Genro Filho.

47 A menção a McLuhan é de Herz.

48 As duas últimas frases deste parágrafo não constam na palestra de Genro Filho (1987a).

49 Essa última frase não consta no áudio da palestra de Genro Filho. Herz também suprime uma frase de Genro Filho que aparece inconclusa na transcrição e como uma frase concluída nas versões publicadas. A frase é: "No meu entendimento, e agora nós vamos aprofundando o conceito de jornalismo, o jornalismo é uma forma de conhecimento baseado no singular, com base na indústria" (GENRO FILHO, 1987, p. Z3; 2007, p. 94). A transcrição coloca uma vírgula após "indústria" e segue até "[...] base na indústria, e digamos assim, que supre uma necessidade... mas uma forma que está intimamente ligada a essa ..." (GENRO FILHO, 1987b - as reticências aqui são da transcrição]". O áudio da palestra apresenta um corte nesse trecho, mas permite a compreensão de mais um pedaço do período: “[...] com base na indústria que, digamos assim, supre uma necessidade dada pela universalização do mundo a partir do desenvolvimento capitalista, mas uma forma que está intimamente ligada a essa [corta o áudio]". Ao verificar o áudio na fita cassete, constatou-se que essa frase é interrompida no final do lado A e o lado B começa com o trecho subsequente. O que sugere que o trecho se perdeu na gravação 
A força do jornalismo é precisamente a singularidade. Os professores que têm uma atividade empírica no jornalismo, mesmo que não teorizem sobre esse problema, acabam se aproximando de certas respostas. Eles nos ensinam, na escola, o modo como empiricamente funciona. "Ao invés de dizer que o sujeito era muito alto, diga que ele tem 1,90m". Lembrando de um exemplo que Nilson Lage dá: "ao invés de dizer que Sarney estava nervoso quando anunciou o último Plano Cruzado, diga que ele tinha o cenho carregado, escreva como suas mãos tremiam, escreva que ele tinha o cenho carregado. Enfim, traduza concretamente. A singularidade é aquilo que é menos generalizante, é aquilo que tem mais força no jornalismo.

São as características específicas, os detalhes que merecem destaque. Porque eu preciso montar um quadro que tenha uma certa semelhança com a minha percepção imediata. Com as coisas que eu vejo ao meu redor. Então é daí que decorre a grandeza e a força do jornalismo. O fato de ele poder descrever coisas distantes pelo ângulo do fenômeno, ou seja, pelo ângulo da sua singularidade. A vocês que recordam os professores que ensinaram a fazer o lead, eles diziam: vocês devem fazer o lead a partir daquilo que é mais exótico, mais estranho ou diferente. A seu modo, os professores estão corretos. Se um sujeito matou o outro e jogou a carteira na frente da delegacia, comecem por aí. "Em frente à delegacia, ontem etc. e tal matou e roubou a carteira". Se um velho de 90 anos mata alguém, o bom jornalista, o jornalista prático, certamente vai começar assim: "com noventa anos..." e assim por diante. Porque o aspecto vivo, o aspecto central do conhecimento que o jornalismo deve formular é a singularidade. É por isso que Adelmo conceitua o jornalismo como uma forma de conhecimento cristalizada no singular, e uma forma que surge historicamente a partir de condições sociais, materiais e técnicas determinadas.

Agora, é evidente que essa forma de conhecimento recebe uma inflexão ideológica, segundo a visão dos intermediários, dos veículos ou dos indivíduos que a

original, no momento de transição de uma fita cassete para outra ou da mudança de lado da fita. 
reproduzem. Isso faz com que tenhamos que partir de uma premissa ${ }^{50}$ : nós não podemos negar que o jornalismo, ao reconstruir o mundo, também trafica toda uma concepção sobre o mundo. Isso é evidente, pois todo o conhecimento social - e o jornalismo é um conhecimento social - envolve um determinado ponto de vista sobre a história, sobre a sociedade, sobre a humanidade. E como a humanidade, a história, é um processo que está em construção permanente, naturalmente, não existe um jornalismo puramente objetivo, ou seja, um jornalismo que seja absolutamente frio, imparcial e neutro. Mas isso decorre não de motivos de ordem psicológica, como dizem certos manuais, como diz, por exemplo, o de Clovis Rossi, "O que é o jornalismo". Não é por motivos psicológicos que o indivíduo está envolvido, mas é porque toda a forma de conhecimento pressupõe um posicionamento do sujeito diante do objeto. Essa é a razão mais profunda, porque o próprio jornalismo implica em uma visão ideológica, implica em um posicionamento ético e político sobre a realidade.

Mas, com isso, nós conseguimos evitar aquele impasse tão tradicional quando se quer fazer uma teoria crítica do jornalismo, quando se quer criticar a dominação burguesa sobre o jornalismo. O que evidentemente deve ser feito, mas que leva muitas vezes a que caiamos no extremo oposto. É de se opor ao jornalismo objetivo, ao jornalismo falsamente objetivo que a burguesia faz e alguns até defendem isso, opondo a isso o jornalismo opinativo. Segundo esse enfoque, o oposto desse jornalismo “objetivo", desse jornalismo que a burguesia faz, seria o jornalismo opinativo. Aquele jornalismo que você pega e abre assim: "com a crueldade que lhes caracteriza, representantes da burguesia ontem reprimiram os trabalhadores na greve". Quer dizer, cheio de adjetivos, cheio de colocações universais, cheio de pressupostos éticos expostos claramente, de onde a singularidade do fato que nós estamos retratando e que nós queremos apreender acaba se perdendo.

50 O início desta frase até esse ponto não faz parte da palestra de Genro Filho. 
$\mathrm{O}$ problema $^{51}$ é que não se trata de dizer aqui que não existe espaço e necessidade para um jornalismo semanal, mensal, de análise, de discussão, um jornalismo de propaganda política e de denúncia. Claro que há. Há necessidade disso e a burguesia tem também vários níveis em que ela aborda esse enfoque e sistematiza a sua comunicação. O que é preciso destacar aqui é que é preciso abordar também o jornalismo diário, o chamado jornalismo objetivo, com a mesma competência e eficácia técnica que a burguesia aborda seus jornais. E essa é uma das principais contribuições deste trabalho de Adelmo, em que ele defende que também é possível realizar esse jornalismo teoricamente concebido. Claro que para isso é preciso ter na mão o jornal. $\mathrm{O}$ jornalismo diário, aparentemente objetivo que a burguesia faz pode ser revertido e pode ser exercido de outro ponto de vista, um ponto de vista crítico, oposto do ponto de vista burguês. Um ponto de vista crítico sobre o regime, sobre o modo de produção e sobre o poder da classe dominante.

Isso não só é possível como extremamente necessário. É uma tremenda ilusão achar que nós vamos combater o poder dominante do país, combater todo o conhecimento que a burguesia produz em seus noticiários, em seus grandes jornais através de pequenos jornais opinativos, onde nós rotulamos, muitas vezes com adjetivos e explicitamos nosso ponto de vista. É indispensável nós pensarmos uma forma de jornalismo que corresponda ao respeito ao leitor, à inteligência do leitor e da curiosidade que o próprio leitor tem em saber o fato, coisa que a burguesia sabe fazer. E, defende Adelmo nesse trabalho, nós podemos fazer a mesma coisa com outro enfoque, com outro ponto de vista de classe.

51 Herz suprime nesse ponto uma frase inconclusa de Genro Filho (1987a; 1987b). Este diz: "O problema é o seguinte: quando eu vou ler uma notícia, não me interessa explicitamente... veja bem, estou falando de jornais diários, o jornalismo tal qual, o conceito de jornalismo diário que corresponde ao jornalismo comum que nós temos aí. Eu não quero dizer que não há necessidade de um jornalismo semanal, mensal, de análise, de discussão, de propaganda política, de denúncia. Claro que há”. Na versão publicada do texto de 1989, há uma adaptação da frase inconclusa que a conclui: "O problema é o seguinte: quando eu vou ler uma notícia, isso não me interessa" (GENRO FILHO, 1989, p. Z3destaque nosso para indicar a adição da palavra). A versão de 2007 altera um pouco mais a frase, mas mantém a conclusão: "O problema é que ,quando eu vou ler uma notícia, isso não me interessa" (GENRO FILHO, 2007, p. 96). 
Adelmo tenta mostrar porque nós podemos fazer isso. Vejam bem, se vocês recordam das categorias do singular, do particular e do universal, observem que há uma inter-relação profunda entre elas. Nós podemos retratar um acontecimento pela via da singularidade e, subjacente a esse acontecimento, nós vamos colocar uma determinada visão particular e universal de mundo. Essa visão vai estar subjacente, ela vai estar superada, grudada na singularidade do fenômeno, vai estar agregada ao retrato da singularidade do fenômeno que nós fazemos. Sem dar opinião alguma no corpo do singular, respeitando as regras do jornalismo como conhecimento produzido no singular, nós podemos dar um enfoque claramente favorável ao sentido que nós queremos dar ao registro que estamos fazendo ${ }^{52}$.

Nessa exposição, Adelmo cita - colhida aleatoriamente - uma matéria que reflete esse tipo de abordagem ${ }^{53}$. É uma matéria sobre o conflito que ocorreu no Congresso entre agricultores que pediam a reforma agrária e os latifundiários da UDR, que tentaram fazer um cordão de isolamento e não deixaram os agricultores tomar as galerias. A matéria citada por Adelmo dizia o seguinte: "Pela manhã, a UDR reinou absoluta nos corredores do Congresso. O presidente da entidade no Rio Grande do Sul, Gilberto Scopel, dava entrevistas à imprensa cercado de 150 militantes gaúchos da organização, todos vestidos a caráter: bombacha, botas e lenço no pescoço". Vejam como a caracterização vai se construindo. "Vindo de um voo charter, especialmente fretado" - e esse é outro dado da matéria e é um fato objetivo que se podia ou não apresentar na matéria, mas é um fato absolutamente objetivo - "especialmente fretado pela organização, os representantes gaúchos da UDR confraternizavam com os colegas

52 Essa última frase é apenas de Herz.

53 Herz suprime um trecho da palestra de Genro Filho para ir diretamente ao exemplo. O trecho é: "Eu vou dar outro exemplo sobre um assunto que é, de certa forma, fácil de fazer porque a maioria dos jornalistas apoia a Reforma Agrária. É uma notícia que saiu hoje na Zero Hora sobre a Reforma Agrária [não consegue encontrar a matéria, barulho de folhas de jornal]. Nesta notícia, sem dar opinião alguma, respeitando as regras do jornalismo como conhecimento produzido através do singular, o jornalista conseguiu dar um enfoque claramente favorável à Reforma Agrária, claramente contrário aos latifundiários e sem emitir qualquer opinião explícita, sem usar qualquer adjetivo qualificativo em relação aos latifundiários, sem dizer se estão com razão ou não" (GENRO FILHO, 1987a). 
de Minas e Espirito Santo. A maioria de jovens filhos de fazendeiro, usando jeans de grifes famosas, camisas polo, muitos de óculos escuros apesar da ausência de sol no interior do Congresso" - e por aí segue a matéria.

O repórter, nessa matéria, foi progressivamente caracterizando, até fisicamente, a posição ideológica dos protagonistas desse episódio ${ }^{54}$, que são aqueles que estão lutando por interesses absolutamente privados. E aqui não há nenhuma apologia à reforma agrária. Isso quer dizer, ele respeitou a sensibilidade, a curiosidade e a inteligência do leitor e com o registro da singularidade do fato, construiu aspectos de particularidade e de universalidade ${ }^{55}$. Agora, não existe uma forma de singularidade, e esse é o problema tanto técnico como ideológico do jornalismo ${ }^{56}$. Existem várias singularidades a depender da universalidade que eu construo no corpo dessa singularidade.

Entre os muitos aspectos singulares que poderíamos retirar desse fato, o repórter selecionando esse, colocou uma determinada inflexão na matéria ${ }^{57}$. Enfim, nesse aspecto existe uma visão particular sobre a UDR, que conceitua a sua natureza, conceitua a UDR, por essa singularidade utilizada, o aspecto ultrarreacionário dos latifundiários e seus objetivos privados. Isso está escrito, mas não está escrito. Há uma concepção universal aqui, favorável à reforma agrária. Não obstante, não há nenhuma frase, nenhum slogan, nenhuma palavra de ordem pela reforma agrária.

Nesse nível de entendimento do jornalismo diário, essa é uma notícia mais eficiente do que uma notícia que começasse por adjetivos. Por exemplo, "A UDR, sabidamente formada por latifundiários conservadores", sem dúvida nenhuma, essa notícia é menos eficiente, porque ela não corresponde à expectativa que o leitor tem de uma compreensão, em um primeiro momento, dos fenômenos tal qual eles ocorrem.

54 Essa consideração é apenas de Herz.

55 Herz adiciona à consideração de Genro Filho o trecho: "[...] e no registro da singularidade do fato, construiu aspectos de particularidade e de universalidade". Por outro lado, suprimiu as seguintes frases presentes na palestra de Genro Filho (1989, p. Z4; 2007, p. 99): "Se eu me interessar pela opinião, vou ler um artigo. Agora, na medida em que eu quero tomar um primeiro contato com os fatos, preciso que essa minha vontade seja respeitada".

56 Essa frase não consta na palestra de Genro Filho.

57 Essa frase não está na palestra de Genro Filho. 
Quer dizer, isso não exclui o jornalismo de combate e o jornalismo de discussão teórica, ideológica e de denúncia, não exclui as outras formas, mas afirma uma natureza e uma legalidade própria do jornalismo. É preciso, portanto, dar combate a esse jornalismo, no nível em que esse jornalismo da burguesia explicita. Com a eficiência que esse jornalismo burguês usa. Então vamos passar a uma visão de classe. O que Adelmo defende exaustivamente é que só é possível fazer isso teoricamente. Só nós compreendendo corretamente o que é o jornalismo que poderemos cumprir essa tarefa. Ou seja, o jornalismo é uma forma de conhecimento centralizada no singular e que essa cristalização no singular tem leis próprias de manifestação. E que é possível, entendendo teoricamente o que é o jornalismo, você trabalhar em uma redação de um Zero Hora, de um Diário Catarinense ${ }^{58}$, enfim, de qualquer jornal do Brasil, qualquer jornal burguês, qualquer jornal da grande imprensa e que nós teremos em significativas ocasiões a oportunidade de passar notícias como esta, que contrariam os interesses dominantes. Quanto mais competentes nós formos ao redigir essas notícias, mais oportunidade elas terão de passar pelos editores, diretores e crivos que se colocam. Quanto mais adjetivos, quanto mais motivos formais nós dermos para a matéria ser barrada, sob a alegação de não ser objetiva, mais possibilidades dessa matéria passar adiante ${ }^{59}$.

Adelmo propõe $\mathrm{e}^{60}$, portanto, uma profunda reflexão sobre a prática cotidiana do jornalismo, do jornalista. Porque a triste realidade é que muitas vezes, sem repressão nenhuma dentro da empresa, de suas editorias ou de suas instâncias de chefia, os

58! Exemplo de Herz. Genro Filho cita o Jornal do Brasil.

59 Herz não lê o trecho: "Eu por exemplo imagino, aqui o editor, não sei quem é, mas se fosse um editor conservador, ele tentou obstar essa notícia mas não teve argumentos. Porque são fatos singulares, objetivos, que aconteceram, que estão dentro da norma e da lógica do jornalismo. Então eu acho que é perfeitamente possível e necessário criar uma concepção baseada nessas premissas. E acredito que essas premissas, aqui expostas, fornecem os elementos básicos para que se venha a desenvolver uma teoria do jornalismo, onde precisamos redefinir coisas como, por exemplo, a pirâmide invertida ou lead" (GENRO FILHO, 1987b; 1989, p. Z4). A versão publicada em livro difere da publicada no Zero e do que está no áudio ou na transcrição. A primeira frase desse trecho, truncada, é substituída por duas frases: "Imagino o editor diante desta matéria sobre a UDR. Não sei quem é, mas mesmo se fosse um editor conservador, não teria argumentos para obstar esta notícia" (GENRO FILHO, 2007, p. 101).

60 Todo esse parágrafo é constituído de reflexões de Herz, sem uso de trechos da transcrição da palestra de Genro Filho. 
jornalistas fazem matérias que se encaixam de forma conservadora na reprodução da ideologia. Mesmo sem repressão, muitos jornalistas que têm uma postura crítica e até mesmo em relação ao capitalismo, acabam fazendo a notícia sob o viés da ideologia burguesa. Porque não têm uma visão teórica que os habilitem a construir a matéria sob uma maneira diferente. E é essa visão que Adelmo tenta oferecer. Esse é o ponto de partida e a grande contribuição que Adelmo dá com esse livro para que esse debate se constitua e para que se busque um caminho teórico e se criem as condições elementares para essa definição e realização desse processo crítico.

Outro aspecto para finalizar o destaque a esse livro de Adelmo e sempre continuando no destaque que ele mesmo fez, na síntese que ele vai fazendo, ele toca em vários aspectos - o livro realmente mais sugere do que resolve certas questões que são da técnica jornalística. Ele cita um deles que é a questão da pirâmide invertida, que é a representação gráfica de um aspecto da técnica jornalística que ressalta - lembrando aqui para os que não são da área - que o mais importante da notícia vem primeiro e em uma ordem decrescente de importância vem o complemento. Por isso que se usa a imagem da pirâmide invertida. A base da pirâmide para cima vai diminuindo do principal para os elementos de menos importância. Bom, Adelmo diz ${ }^{61}$ que isso até pode corresponder a uma média dos casos. Em geral, realmente o mais importante vem no início. Agora, isso não nos diz nada sobre a natureza do jornalismo como forma de conhecimento.

Então, Adelmo, com essa abordagem, ele inverte a pirâmide, dizendo o seguinte: o segredo da pirâmide é que ela está invertida. Por que ela está invertida? Porque se pensarmos a pirâmide em pé, o ângulo para cima e base embaixo, nós vamos ter um raciocínio mais apropriado para referir à essência do jornalismo. Qual seja, que a notícia jornalística caminha da sua formulação do singular, o aspecto mais agudo, para os aspectos mais particulares. Então, se eu tenho um ângulo fechado em cima, esse ponto é precisamente o ponto do lead, o ponto da máxima singularidade. Quando formulamos o

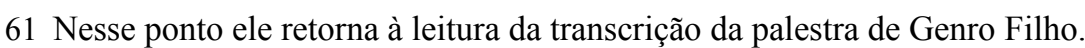


início da notícia, destacamos aqueles aspectos que são próprios do fenômeno, diferente de todos os outros ${ }^{62}$. Nós procuramos, o jornalista competente procura automaticamente, empiricamente o fenômeno ${ }^{63}$. À medida que vou desenvolvendo a notícia, vou caminhando para a localização desse fato em um terreno particular, um terreno mais abrangente. Então eu vou situar dentro de uma determinada conjuntura as situações em que um fato aconteceu, enfim, vou chegar a uma base particular dessa formulação.

E o universal, onde vai estar? O universal não vai estar contido na pirâmide. O universal, para manter a lógica, a forma gráfica da pirâmide, o universal, os princípios universais, mais gerais, serão uma continuidade que estará subjacente à apreensão feita. Então, na imagem gráfica que Adelmo utiliza, é mantida a pirâmide íntegra naquele ângulo mais agudo de lead na parte de cima e os vértices dos dois lados se projetam em uma continuidade pontilhada e abrem o ângulo da parte de cima. Essa imagem vale, de forma muito grosseira, para chamar a atenção para o seguinte ${ }^{64}$ : que graficamente, essa representação epistemológica, como representação do conhecimento que o jornalismo encerra, está invertida. O conhecimento jornalístico, a notícia, caminha não do mais importante para o menos importante, pois há casos até mesmo que isso não ocorre. Mas ela é uma forma de conhecimento que caminha do singular para o particular, porque a singularidade é a essência da notícia. Então o lead vai estar no começo, o que inclusive não é obrigatório. Mesmo que o lead não esteja no começo, a construção da notícia como um todo é da singularidade, ou seja, do específico para essa generalização capaz de situar o fato no tempo e na história ${ }^{65}$.

62 Herz não cita a frase que viria a seguir: "Procuro as diferenças".

63 Esta frase não está na palestra de Genro Filho.

64 Da frase anterior até esse ponto, as considerações são de Herz.

65 As versões publicadas em 1989 e 2007, utilizadas para o cotejamento, terminam o texto nesse ponto, excluindo o último parágrafo lido na palestra e os dois últimos parágrafos do áudio e da transcrição. 
$\mathrm{E}^{66}$ assim é que nós devemos tratar os fatos no jornalismo, pela sua singularidade. Nós precisamos desenvolver uma visão teórica sólida sobre isso. Para podermos fazer um jornalismo desse tipo. Porque normalmente, um pouco pela ideologia dominante na pequena burguesia, que é uma ideologia de conciliação de classes, uma ideologia de capitulação diante da opressão, mas um pouco também pela fragilidade teórica com que nós saímos da faculdade e vamos trabalhar nos jornais reproduzindo a ideologia burguesa com a mesma ingenuidade, com a mesma naturalidade com que compramos cigarros no bar da esquina ${ }^{67}$. Nós fazemos isso sem querer. Até porque quando queremos não temos uma base teórica para compreender quais as leis eu preciso para reconhecer e aplicar para fazer uma notícia jornalística objetiva a partir de outro enfoque político e ideológico.

\section{III}

Essa é uma síntese feita pelo próprio Adelmo, da qual eu procurei ser o portador da sua obra. Eu vou concluir minha exposição destacando uns três ou quatro pontos sobre o livro em si, ou seja, projetando aspectos da importância desse livro, alguns dos quais ultrapassam as fronteiras de discussão da área de comunicação. Um dos pontos que merece destaque é a análise que vincula o funcionalismo ao senso comum e que

66 Herz suprime um parágrafo presente na transcrição e no áudio da palestra de Genro Filho. Trata-se de um exemplo dado por Genro Filho ao parágrafo anterior. "Quando eu digo situar o fato socialmente, na história, eu não quero dizer fazer um tratado científico, de sociologia, de história, absolutamente. Nada disso. É situar com outros acontecimentos. Fazer relações elementares com outros acontecimentos que estão vinculados a esse acontecimento chave. Então, digamos assim, se eu descrever Luciano como um fato jornalístico, eu partiria da definição daquilo que fosse mais característico, mais específico dele, diferente de todo mundo. Então eu diria assim: "Luciano é um sujeito que lê Hegel em alemão". Com isso eu começaria uma definição jornalística de Luciano. Eu começaria um tipo de definição jornalística. Aí vocês diriam: "Pô, o cara lê Hegel em alemão!" Quer dizer, esse é o fato mais singular. Depois, eu diria outros fatos. "É um sujeito interessado em tais e tais coisas, em filosofia, pretende se especializar em jornalismo, tem traços de caráter de generosidade, etc. A partir disso, vou ampliando, vou abrindo, digamos assim, a generalidade das coisas que eu vou dizendo sobre ele. Ao final, vocês teriam uma primeira impressão muito viva sobre Luciano, do que ele é pessoalmente, de algumas características gerais dele e de outras somente dele".

67 Figura de linguagem também utilizada no encerramento do segundo capítulo de "O Segredo da Pirâmide" (cf. GENRO FILHO, 2012, p. 48). 
justifica por isso sua eficácia e sua disseminação. É sem dúvida uma análise original e que transcende o debate da área de comunicação, pois levanta importantes questões para a sociologia. Outro ponto que merece destaque é a crítica à teoria dos sistemas, embora bastante sintética, bastante limitada no livro, é um importante acerto de contas do marxismo com essa abordagem. E ela, embora não resolva questões, nem uma parte dessas questões, abre caminhos para uma crítica mais profunda aos limites da teoria dos sistemas, o que é extremamente importante hoje, porque a abordagem da teoria dos sistemas impregna o pensamento e muitas das expressões do pensamento burguês contemporâneo e até de determinadas vertentes marxistas, especialmente em se tratando das teorias soviéticas que veem nas teorias dos sistemas um registro do movimento das coisas, uma expressão correta da maneira coisificada com que a teoria soviética trata a realidade. Enfim, essa abordagem da teoria dos sistemas é uma contribuição importante desse livro.

Outro aspecto que merece destaque é a crítica à Escola de Frankfurt e ao que Adelmo chamou de reducionismo ideológico do jornalismo em que atacou em um ponto nevrálgico - embora ele tenha feito uma síntese de várias contribuições, ele tocou em um ponto nevrálgico - que na área da comunicação é decisiva, ou seja, atacar essas concepções marxistas que preveem a extinção da filosofia assim como a extinção do jornalismo.

Outras contribuições como essas, como a descoberta do segredo da pirâmide e a inversão do lead são realmente lances de genialidade, que mostram a aplicabilidade técnica do enfoque teórico levantado no livro. Com esse enfoque sobre o lead, Adelmo levanta a bola, mas ainda está longe de resolver o tratamento das questões técnicas a partir do trabalho teórico. Mas ele mostra a aplicabilidade dessa abordagem teórica, e está aberto para nós aqui a necessidade de trabalhar em cima disso, de aprofundar esse tipo de enfoque, traduzir tecnicamente essa abordagem teórica.

Outra contribuição muito importante é o desvendamento do sujeito coletivo que se expressa no jornalismo. A produção industrial, diz Adelmo, acaba com a falsa 
aparência que são os indivíduos que estão falando no jornalismo. O jornalismo da era industrial deixa claro, deixa visível que o sujeito que realmente se expressa são classes sociais, são grupos econômicos, enfim, são coletividades. Não é o indivíduo. Então, além da crítica ao atual sistema de coisas, ao atual sistema marcado pela dominação burguesa, esse enfoque descortina uma discussão crucial para a análise do papel dos meios de comunicação em uma sociedade socialista, principalmente através da expressão. Qual estatuto deve deter o sujeito coletivo que se expressa através dos meios de comunicação? É impossível prever uma sociedade comunista sem discutir essa equação que originalmente foi levantada por Adelmo.

Finalmente, ele elevou o jornalismo de uma mera técnica literária a uma forma de conhecimento, o que é um gesto teórico audacioso. Equiparar o jornalismo à arte e à ciência é uma das conclusões que, poderíamos dizer, bombásticas do livro, teoricamente inquietante, instigante. E esse enfoque levanta questões cruciais para o futuro dos meios de comunicação de massa. Adelmo, portanto, apresenta o jornalismo como uma forma de conhecimento que, juntamente com a arte e a ciência, constitui o sujeito individual e social no interior do gênero humano. "Para isso", conclui Adelmo, é a última frase do livro dele e que vale a pena ser referida, "para isso, o homem precisa viver concretamente e não apenas através de mediações particulares e universais da arte e da ciência. A totalidade do mundo humano traz determinações significativas do singular. A realização do comunismo, portanto, não pode ser pensada sem o pleno desenvolvimento dessa forma social de apreensão da realidade a que chamamos jornalismo informativo".

Por fim, a inserção ${ }^{68}$, não vou me deter aqui sobre isso porque eu me estendi demais. Eu fiz questão de detalhar tanto essa abordagem e esses aspectos porque acho que é de interesse. Não havia combinado antes com Eduardo ${ }^{69}$, acho que é um inventário que talvez ajude a essa discussão que o curso de jornalismo faz aqui, particularmente. E gostaria de ter levantado alguns elementos que, embora eu não tenha

68 Possivelmente seja a inserção do livro nos debates mais amplos que Genro Filho empreendia na política e na filosofia. A hesitação e leve confusão de Herz foram mantidas.

69 Provavelmente, trata-se de Eduardo Meditsch, quem estava na mesa do Seminário neste dia. 
assinalado, estabelecessem os nexos desta obra de Adelmo no conjunto da obra dele, visto que este livro ${ }^{70}$ adquiriu importância, como destacamos, por ser a obra mais acabada dele. Agora, a relação do livro com a obra dele, eu gostaria de fazer com as próprias palavras de Adelmo, porque eu acho que ninguém melhor do que ele para situar qual foi a intenção desse livro, qual foi a perspectiva que o orientou a fazer esse esforço que ele mesmo dizia ser um esforço inicial, uma levantada da bola, de um assunto que tem tantos desdobramentos. Então, eu acho que ninguém melhor do que ele para completar esse motivo de memória que há aqui, que tem esse evento. Eu gostaria de terminar colocando as próprias palavras de Adelmo para expressar - a conclusão da palestra dele na $\mathrm{PUC}^{71}$ - a relação dessa obra com o tipo de marxismo que ele postulava.

[...] O que eu estou tentando fazer é uma análise do jornalismo de um ponto de vista filosófico e metodológico que eu entendo marxista. Quer dizer, eu acho que toda a realidade deve ser analisada segundo um ponto de vista, segundo critérios, segundo algumas premissas teóricas. No meu entendimento, um certo marxismo, ou seja um marxismo não dogmático, é a maneira mais radical de enxergar o mundo, ou seja você enxerga mais a raiz, você se compromete mais humanamente com esse mundo. Eu acho que o marxismo entendido assim, e não entendido dogmaticamente como a solução religiosa para tudo, mas como uma metodologia, como um compromisso histórico, ele é o viés, é a lente que te permite enxergar o mundo de forma mais realista. $\mathrm{O}$ importante é se comprometer com esse mundo no âmbito coletivo. Agora isso não quer dizer que eu esteja propondo uma divulgação jornalística do marxismo. Acho que não, vai divulgar a realidade. Eu acho que o jornalismo vai ter que colocar em pauta os fenômenos que acontecem. O objeto de trabalho dele é a informação, é a realidade tratada de uma determinada forma. O que eu estou propondo é o entendimento desse processo. Eu acho que as premissas entendidas assim, no marxismo, acho que permitem o entendimento desse processo. Então, eu acho que cada análise concreta que se consegue fazer, se no caso se essa análise que eu fiz tenha algum fundamento, alguma validade, por menor que seja, isso engrandeceria o marxismo, pois daria uma aplicabilidade real para ele, mostrando que é um método que pode ser utilizado com o entendimento e a consciência. Se não tiver nenhum fundamento, aí talvez seja até um prejuízo para o marxismo, uma coisa chamada de marxista e que não tem nenhum fundamento. Mas isso só o tempo vai dizer.

70 O trecho "visto que este livro" foi incluído por mim para manter o sentido expresso na linguagem falada sem a ambiguidade que o transladar à linguagem escrita causa.

71 Trata-se da resposta à última questão formulada pela plateia presente na gravação em áudio e não da conclusão da palestra de Genro Filho. 
Transcorridos menos de um ano da publicação dessa obra, cresce a convicção de que esse trabalho só pode engrandecer o marxismo. E sua aplicabilidade, como o próprio Adelmo falou, não é algo abstrato. Os testes de sua aplicabilidade dependem hoje exclusivamente de nós. Isso é um compromisso que marcou toda sua vida, de construção de uma humanidade melhor e que se impõe para nós como compromisso que deve ser cotidianamente reassumido. Espero que a saudade de Adelmo, que certamente fere todos que com ele conviveram, nesse momento, seja traduzida como alento nessa luta que não tem fim. 


\section{Referências Consultadas}

GENRO FILHO, Adelmo. Sem Título. Versão em áudio. Palestra proferida no Encontro Regional dos Estudantes da Comunicação (ERECOM). Pontifícia Universidade Católica do Rio Grande do Sul, 1987a. GENRO FILHO, Adelmo. Sem Título (Transcrição sem revisão final). Versão datilografada. Palestra proferida no Encontro Regional dos Estudantes da Comunicação (ERECOM). Pontifícia Universidade Católica do Rio Grande do Sul, 1987b.

GENRO FILHO, Adelmo. Jornalismo já tem sua teoria. Adelmo Genro Filho abre um novo caminho para a reflexão. Jornal Laboratório Zero. Caderno Z Especial. Curso de Comunicação Social, habilitação em Jornalismo. Universidade Federal de Santa Catarina. Florianópolis, setembro de 1989.

GENRO FILHO, Adelmo. O Segredo da Pirâmide: para uma teoria marxista do jornalismo. Palestra proferida no Encontro Regional dos Estudantes da Comunicação (ERECOM). In: AMARAL, Márcia F et al. A Contribuição de Adelmo Genro Filho. Santa Maria: FACOS, 2007, p. 79-102.

GENRO FILHO, Adelmo. O Segredo da Pirâmide: para uma teoria marxista do jornalismo. Florianópolis: Insular, 2012.

KLEIN, Eloisa Joseane C. Nas veias do jornalismo, a política: resistência à ditadura no informação.

Dissertação. Programa de Pós-Graduação em Ciências da Comunicação, Universidade do Vale do Rio dos Sinos. São Leopoldo: Unisinos, 2008. Disponível em

$<$ http://www.dominiopublico.gov.br/download/texto/cp083756.pdf $>$. Acesso em: 25 out 2012.

OSÓRIO, Pedro Luiz da S. O Segredo da Pirâmide: algumas notas e lembranças. In: AMARAL, Márcia F et al. A Contribuição de Adelmo Genro Filho. Santa Maria: FACOS, 2007, p. 37-49

REIS, Eliana Tavares dos. Juventude, Intelectualidade e Política: espaços de atuação e repertório de mobilização no MDB dos anos 70. Dissertação. Programa de Pós Graduação em Ciência Política, Universidade Federal do Rio Grande do Sul. Porto Alegre: UFRGS, 2001. Disponível em:

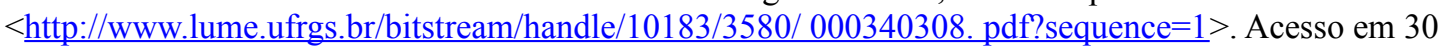
dez. 2012

Este artigo e todo o conteúdo da Estudos em Jornalismo e Mídia estão disponiveis em http://www.periodicos.ufsc.br/index.php/jornalismo/index

Estudos em Jornalismo e Mídia está sob a Licença Creative Commons 